\title{
Response of Yellow Maize Yield to Preceding Crop Effect and NP Fertilization Level
}

E.E.A. El-Sobky

Agronomy Dept., Fac. Agric., Zagazig Univ., El-Sharkia, Egypt.

\begin{abstract}
HIS STUDY was conducted in the Experimental Farm, Ghazala 1 Village, Faculty of Agriculture, Zagazig University, El-Sharkia Governorate, Egypt, during two successive seasons (2014 and 2015). The study aimed to find out the effect of preceding crop (berseem and wheat), phosphorus "P" $\left(0,15.5\right.$ and $\left.31 \mathrm{~kg} \mathrm{P}_{2} \mathrm{O}_{5} / \mathrm{fad}^{*}\right)$ and nitrogen "N" (40, 80 and $120 \mathrm{~kg} \mathrm{~N} /$ fad) levels on yellow maize yield and its attributes. The results clearly clarified the possibility of saving $\mathrm{N}$ additions when maize was preceded by berseem than when preceded by wheat. Though ear length and diameter and the grain set per ear as expressed in the number of rows per ear, number of grains per row, number of grains per ear and total yield/ fad were not significantly increased, however, grain filling as expressed in seed index and grain weight per ear were significantly increased due to growing maize after berseem and hence the grain and ears yields per fad, shelling percentage and harvest index were increased compared with growing maize after wheat. Regarding $\mathrm{P}$ levels effect, the first increment (15.5 $\mathrm{P}_{2} \mathrm{O}_{5} / \mathrm{fad}$ ) was quite enough for increasing grain yield per fad and almost all of its attributes, where the further increase in $\mathrm{P}$ level did not add any significant increase in this respect. Finally, the grain yield, ears yield and hence the total yield per fad responded to each $\mathrm{N}$ increment up to $120 \mathrm{~kg} \mathrm{~N} / \mathrm{fad}$, but, the stover yield responded to only $80 \mathrm{~kg} \mathrm{~N} / \mathrm{fad}$ and hence the harvest index was the highest $(41.30 \%)$ at the lowest $\mathrm{N}$ level $(40 \mathrm{~kg} \mathrm{~N} / \mathrm{fad})$. The most frequent first order interaction between factors under study was that between the preceding crop and $\mathrm{N}$ levels which indicated the need of lower $\mathrm{N}$ level in order to maximize the grain yield per fad when maize was preceded by berseem compared with after wheat. The grain yield response to $\mathrm{N}$ level was diminishing where $50.8 \mathrm{~kg} \mathrm{~N} / \mathrm{fad}$ were needed to maximize the grain yield to $3.03 \mathrm{ton} / \mathrm{fad}$ compared with $105.7 \mathrm{~kg} \mathrm{~N} /$ fad needed to maximize the grain yield to only $2.89 \mathrm{ton} /$ fad when maize was preceded by berseem and wheat, respectively.
\end{abstract}

Keywords: Maize, Preceding crop, P, N, Grain yield.

In Egypt, attempts are being devoted to optimize the use of irrigation water through reducing the rice cultivated area to about one million faddan instead of twice of this area. Accordingly, the maize (Zea mays L.) cultivated area is expected to be extended to more than 1.79 million faddan (FAOSTAT, 2014). This extension dictates growing some of the maize area after wheat and mainly after berseem. Therefore, studies should focus on the response of maize to the effects of the preceding crop, i.e. wheat and berseem which occupy most of the cultivated area during winter. The favourable effects of legumes in enriching soil

*ad $=$ faddan $=4200 \mathrm{~m}^{2}$ and ha $=2.4 \mathrm{fad}$ 
fertility from physical, chemical and biological points of view cannot be denied and are extensively reported in the literature (Chan \& Heenan, 1996; Bagayako et al., 2000; and Yusuf et al., 2009 and Zivorad et al., 2013). The extensive use of mineral fertilizers has masked most of the beneficial effects of crop rotation. Karlen et al. (1994) stated that no amount of mineral fertilizer can be fully compensated for crop rotation beneficial effects. Grain yield response of maize to applied P was greater when the preceding crop was maize compared with soybean. This may have been because of greater net release of $\mathrm{P}$ from soil organic matter and crop residues when the previous crop was soybean (Wortmann et al., 2009). Succession of grasses in the crop rotation needs enriching soil fertility from plant nutrients and in particular from $\mathrm{N}$ and $\mathrm{P}$.

Several studies have been carried out to find out the response of maize to $\mathrm{P}$ fertilization. Saleem et al. (2003) showed that, maize grain yield was significantly affected by $\mathrm{P}$ levels where the highest yield average was produced at $29 \mathrm{~kg} \mathrm{P}_{2} \mathrm{O}_{5} / \mathrm{fad}$ followed by 25, 33, $21 \mathrm{P}_{2} \mathrm{O}_{5}$ /fad and control. Also, Hegazy et al. (1996), Omar (2014), Salem, (2000), Hussein (2009), Masood et al. ( 2011) and Abd El-Rheem et al. ( 2015) showed that, the increase $\mathrm{P}$ levels up to $15,25,30,38,42$ and $80 \mathrm{~kg}_{2} \mathrm{O}_{5} / \mathrm{fad}$ increased grain yield, biomass and its components. While, Skarlou \& Nuhas (1981) and Mazengia (2011) showed that, application of mineral P was without any significant effect on maize yield and its attributes.

Mineral fertilization with nitrogen was also reported to increase yield of maize. Mahama et al. (2016), Shams (2000), El-Murshedy (2002) and Kandil (2013) reported that, the increase of $\mathrm{N}$ level up to $75,120,140$ and $150 \mathrm{~kg} \mathrm{~N} /$ fad increased grain yield and its components i.e. number of rows/ ear, number of grains/ row, 100 kernels weight and grain weight. These increases were attributed to the increase of yield attributes, i.e. plant height, ears/ plant, ear length and diameter (Ghazy, 2004; Abd-Alla, 2005; Atia \& Mahmoud, 2006; Soliman \& Gharib, 2011; El-Azab, 2012; Darwich, 2013 and Abd El-Rheem et al., 2015). Synergistic relationship between N and $\mathrm{P}$ may convert relatively unavailable native and residual $\mathrm{P}$ to available forms which are ready for uptake by plants (Ogunlela et al., 2005).

Therefore, the present study was devoted to find out the response of yellow maize to the effect of the preceding crop (berseem and wheat) under different levels from $\mathrm{P}\left(0,15.5\right.$ and $31 \mathrm{~kg} \mathrm{P}_{2} \mathrm{O}_{5} /$ fad $\left.^{*}\right)$ and $\mathrm{N}(40,80$ and $120 \mathrm{~kg} \mathrm{~N} / \mathrm{fad})$ and their interactions.

\section{Materials and Methods}

The present study was conducted in the Experimental Station at Ghazala Village, Fac. Agric., Zagazig Univ., Sharkia Governorate, Egypt (30.11 ${ }^{\circ} \mathrm{N}$, $31.41^{\circ} \mathrm{E}$ ) during two successive summer seasons of 2014 and 2015. The study aimed to find out the effect of preceding crop treatments, phosphorus $(\mathrm{P})$ and nitrogen $(\mathrm{N})$ fertilization levels on maize yield. 


\section{Studied factors}

Preceding crop treatments

1. Berseem (Trifolium alexandrinum L.) (Legume forage crop).

2. Wheat (Triticum aestivum L.) (Spring wheat, bread wheat).

Phosphorus fertilization levels

1. Check.

2. $15.5 \mathrm{~kg} \mathrm{P}_{2} \mathrm{O}_{5} / \mathrm{fad}$.

3. $31 \mathrm{~kg} \mathrm{P} \mathrm{O}_{5} / \mathrm{fad}$.

Nitrogen fertilization levels

$1.40 \mathrm{~kg} \mathrm{~N} / \mathrm{fad}$.

2. $80 \mathrm{~kg} \mathrm{~N} / \mathrm{fad}$.

3. $120 \mathrm{~kg} \mathrm{~N} / \mathrm{fad}$.

Phosphorus as ordinary superphosphate $\left(15.5 \% \mathrm{P}_{2} \mathrm{O}_{5}\right)$ was band placed at planting. Ammonium nitrate $(33.5 \% \mathrm{~N})$ was partly applied in two splits before the first and second irrigations at 20 and 34 days after planting (DAP). A splitsplit plot design with four replications was used, where the preceding crop treatments were allocated in the main plots, whereas, $\mathrm{P}$ and $\mathrm{N}$ levels were allocated in the first and second order sub plots $\left(17.5 \mathrm{~m}^{2}\right)$, respectively.

\section{Recorded data}

Maize yield and yield attributes

At harvest, (120 DAP), the following yield attributes were recorded on ten maize plants and ears: ear diameter, ear length $(\mathrm{cm})$, rows number per ear (No.), grains number per row (No.), grains number per ear (calculated), hundred grain weight $(\mathrm{g})$, shelling percentage $(\%)$ and grain weight per ear $(\mathrm{g})$. Also, the following final yield traits were recorded from the two central ridges: grain yield (ton/fad): at grain moisture content of $15.5 \%$, ears yield, total yield, stover yield (ton/fad) and harvest index (\%) i.e., grain to total yield in percentage.

\section{General agronomic practices}

Single cross 173 yellow maize cultivar was planted on May $20^{\text {th }}$ in both seasons. Each sub plot $(3.5 \mathrm{~m} \times 5 \mathrm{~m})$ included 5 ridges $70 \mathrm{~cm}$ apart. Seeds were hand sown on one side of the ridge in hills $25 \mathrm{~cm}$ apart. Planting was made after berseem and wheat as preceding using seeding rate of $10 \mathrm{~kg} / \mathrm{fad}$. Plants were thinned to one plant per hill (24000 plant/ fad) before the first irrigation (20 DAP) and flood irrigation was practiced every 14 days. Soil samples were taken from the two preceding crop sites (berseem and wheat) at a depth of $0-30 \mathrm{~cm}$ before planting to determine soil physical and chemical properties at the Central Laboratory of Faculty of Agriculture, Zagazig University, Zagazig, Egypt (Table 1-a).

\section{Statistical analysis}

Data were statistically analyzed according to Gomez \& Gomez (1984) by using MSTAT-C (1991) where statistical program Version 2.1 was used for analysis of variance (ANOVA). A combined analysis was undertaken for the data 
of the two seasons after testing the homogeneity of the experimental errors. Duncan Multiple range test was used to compare statistical significant differences (Duncan, 1955). In interaction Tables, capital and small letters were used to denote significant differences among rows and columns means, respectively. Interaction Tables are provided with response equations to compare the response of maize yield and its attributes to the increase of $\mathrm{N}$ level at the two preceding crop treatments. The response equations were calculated according to Snedecor \& Cochran (1967) using the orthogonal polynomial Tables. The significance of the linear and quadratic components of each of equation was tested, then the response could be described as linear (first order) or quadratic (second order). The predicted maximum averages $\left(\hat{\mathrm{Y}}_{\max }\right)$ which could have been obtained due to the addition of the predicted maximum $\mathrm{N}$ level $\left(\mathrm{X}_{\max }\right)$ were calculated according to Neter et al. (1990) as explained by Abdul Galil et al. (2003) using the following equations:

$$
\hat{\mathrm{Y}}_{\max }=\hat{\mathrm{Y}}_{0}+\mathrm{b}^{2} / 4 \mathrm{c} \quad \mathrm{X}_{\max }=\mathrm{X}_{0}+\mathrm{b} / 2 \mathrm{c}(\mathrm{u})
$$

where: $\hat{\mathrm{Y}}_{0}=$ Grain yield at the lowest $\mathrm{N}$ level i.e. $40 \mathrm{~kg} \mathrm{~N} / \mathrm{fad}$ (ton/ fad).

$\mathrm{b}=$ Measures the linear component of the response equation.

$\mathrm{c}=$ Measures the quadratic component of the response equation.

$\mathrm{u}=$ unit of $\mathrm{N}=40 \mathrm{~kg} \mathrm{~N} / \mathrm{fad}$.

Climate conditions

Data in Table 1-b show the monthly mean minimum and maximum air temperatures, relative humidity, wind speed and precipitation during the two maize growing seasons.

TABLE1-a. Physical and chemical analyses of the experimental soil sites at $30 \mathrm{~cm}$ depth (average of two seasons).

\begin{tabular}{|l|c|c|c|c|c|c|}
\hline $\begin{array}{l}\text { Preceding } \\
\text { crop }\end{array}$ & $\begin{array}{c}\text { Organic } \\
\text { matter } \\
(\boldsymbol{\%})\end{array}$ & $\begin{array}{c}\text { Total N } \\
(\boldsymbol{\%})\end{array}$ & $\begin{array}{c}\text { Available } \mathbf{P} \\
\left(\mathbf{m g ~ k g}^{-1}\right)\end{array}$ & $\begin{array}{c}\text { Available } \\
\mathbf{K}\left(\mathbf{m g ~ k g}^{-1}\right)\end{array}$ & $\mathbf{p H}^{*}$ & Texture \\
\hline Berseem & 2.0 & 0.15 & 17 & 140 & 7.9 & Clay \\
\hline Wheat & 1.04 & 0.05 & 8.95 & 148 & 7.99 & Clay \\
\hline
\end{tabular}

* Soil suspension

TABLE 1-b. Monthly mean minimum and maximum air temperatures, relative humidity, wind speed and precipitation during the two maize growing seasons ${ }^{*}$

\begin{tabular}{|c|c|c|c|c|c|c|}
\hline \multirow{2}{*}{ Month } & \multicolumn{3}{|c|}{ Temperature ( $\mathrm{C}$ ) } & \multirow{2}{*}{$\begin{array}{c}\text { Relative } \\
\text { humidity } \\
(\%)\end{array}$} & \multirow{2}{*}{$\begin{array}{c}\text { Wind } \\
(\mathrm{km} / \mathrm{h})\end{array}$} & \multirow{2}{*}{$\begin{array}{l}\text { Precipitation } \\
\text { (mm) }\end{array}$} \\
\hline & Max. & Min. & Mean & & & \\
\hline \multicolumn{7}{|c|}{2014 season } \\
\hline May & 42 & 25 & 33.5 & 71 & 13 & 0.00 \\
\hline June & 43 & 29 & 36 & 73 & 12 & 0.00 \\
\hline July & 39 & 31 & 35 & 82 & 10 & 0.00 \\
\hline August & 38 & 32 & 35 & 83 & 10 & 0.00 \\
\hline September & 39 & 28 & 33.5 & 74 & 9 & 0.00 \\
\hline \multicolumn{7}{|c|}{2015 season } \\
\hline May & 44 & 27 & 35.5 & 76.4 & 10 & 0.00 \\
\hline June & 40 & 28 & 34 & 77.4 & 10 & 0.00 \\
\hline July & 41 & 30 & 35.5 & 85.2 & 8 & 0.00 \\
\hline August & 42 & 33 & 37.5 & 80.9 & 10 & 0.00 \\
\hline September & 39 & 33 & 36 & 78.7 & 10 & 0.00 \\
\hline
\end{tabular}

http:// www.wunderground.com

Egypt. J. Agron.38, No. 2 (2016) 


\section{Results and Discussion}

\section{Maize grain yield attributes}

Ear length and diameter

Preceding crop effect: Ear length and diameter were not significantly affected by varying the preceding crop in both seasons. However, the combined analysis detected significant increase in ear diameter of maize grown after berseem (Table 2).

TABLE 2. Ear length and diameter of maize as affected by preceding crop treatments, phosphorus and nitrogen fertilization levels and their interactions in both seasons and their combined.

\begin{tabular}{|c|c|c|c|c|c|c|}
\hline \multirow{2}{*}{$\begin{array}{l}\text { Main effects and } \\
\text { interactions }\end{array}$} & \multicolumn{3}{|c|}{ Ear length (cm) } & \multicolumn{3}{|c|}{ Ear diameter $(\mathrm{cm})$} \\
\hline & 2014 & 2015 & Comb. & 2014 & 2015 & Comb. \\
\hline \multicolumn{7}{|l|}{ Preceding crop treatments $(\mathrm{C})$} \\
\hline Berseem & 17.81 & 17.96 & 17.88 & 4.60 & 4.58 & 4.59 \\
\hline Wheat & 17.68 & 17.75 & 17.71 & 4.35 & 4.36 & 4.36 \\
\hline F-test & N.S. & N.S. & N.S. & N.S. & N.S. & $* *$ \\
\hline \multicolumn{7}{|l|}{ Phosphorus level (P): } \\
\hline Check & 17.46 & 17.48 & $17.47 \mathrm{~b}$ & $4.41 \mathrm{~b}$ & 4.41 & $4.41 \mathrm{~b}$ \\
\hline $15.5 \mathrm{~kg} \mathrm{P}_{2} \mathrm{O}_{5} / \mathrm{fad}$ & 17.97 & 18.23 & $18.10 \mathrm{a}$ & $4.52 \mathrm{a}$ & 4.51 & $4.52 \mathrm{a}$ \\
\hline $31 \mathrm{~kg} \mathrm{P}_{2} \mathrm{O}_{5} / \mathrm{fad}$ & 17.80 & 17.84 & $17.82 \mathrm{a}$ & $4.50 \mathrm{a}$ & 4.49 & $4.50 \mathrm{a}$ \\
\hline F.test & N.S. & N.S. & $*$ & $* *$ & N.S. & $* *$ \\
\hline \multicolumn{7}{|l|}{ Nitrogen level $(\mathrm{N})$ : } \\
\hline $40 \mathrm{~kg} \mathrm{~N} / \mathrm{fad}$ & $16.75 \mathrm{~b}$ & $16.90 \mathrm{~b}$ & $16.83 b$ & $4.41 \mathrm{c}$ & $4.42 \mathrm{~b}$ & $4.42 \mathrm{c}$ \\
\hline $80 \mathrm{~kg} \mathrm{~N} / \mathrm{fad}$ & $18.18 \mathrm{a}$ & $18.22 \mathrm{a}$ & $18.20 \mathrm{a}$ & $4.49 \mathrm{~b}$ & $4.48 \mathrm{a}$ & $4.49 \mathrm{~b}$ \\
\hline $120 \mathrm{~kg} \mathrm{~N} / \mathrm{fad}$ & $18.30 \mathrm{a}$ & $18.44 \mathrm{a}$ & $18.37 \mathrm{a}$ & $4.52 \mathrm{a}$ & $4.52 \mathrm{a}$ & $4.52 \mathrm{a}$ \\
\hline F.test & $* *$ & $* *$ & $* *$ & $* *$ & $* *$ & $* *$ \\
\hline \multicolumn{7}{|l|}{ Interactions: } \\
\hline $\mathrm{C} \times \mathrm{P}$ & N.S. & N.S. & N.S. & N.S. & N.S. & N.S. \\
\hline $\mathrm{C} \times \mathrm{N}$ & $* *$ & N.S. & $* *(2-a)$ & $* *$ & N.S. & $* *(2-c)$ \\
\hline $\mathrm{P} \times \mathrm{N}$ & $* *$ & N.S. & $* *(2-b)$ & $*$ & N.S. & N.S. \\
\hline
\end{tabular}

and N.S. indicate statistically significant at 0.05 and 0.01 levels and insignificancy of differences, respectively.

Phosphorus level effect: Ear length was not significantly affected by P level in both seasons, however, the combined analysis detected significant increase due to addition of $\mathrm{P}$ at either levels which had at par averages. This significant effect was observed in ear diameter in the first season and the combined of both seasons (Table 2). These results refer to the need of maize plants to added $\mathrm{P}$ at only the lower level, i.e. $15.5 \mathrm{~kg} \mathrm{P}_{2} \mathrm{O}_{5} /$ fad where the further increase in $\mathrm{P}$ level did not add a significant increase in either length or ear diameter. These results are in harmony with those obtained by Hegazy et al. (1996), Saleem et al. (2003) and Omar (2014), while, not in accordance with those reported by Hussein (2009), Masood et al. (2011) and Abd El-Rheem et al. (2015) as they reported more response to added $\mathrm{P}$ than that observed herein.

Nitrogen level effect: In both seasons and their combined, the increase of $\mathrm{N}$ level to 80 or $120 \mathrm{~kg} \mathrm{~N} /$ fad produced at par significant increase in ear length, which was also observed in ear diameter in the second season. However, ear diameter in the first season and the combined analysis detected consistent 
significant increase with each increase in $\mathrm{N}$ level up to the addition of $120 \mathrm{~kg} \mathrm{~N} /$ fad (Table 2). These results indicated that ear diameter was more affected by increasing $\mathrm{N}$ level than ear length. Similar findings were reported by Ghazy (2004), Abd-Alla (2005), Atia \& Mahmoud (2006), Soliman \& Gharib (2011), ElAzab (2012), Darwich (2013) and Abd El-Rheem et al. (2015).

Interaction effect:Significant interaction effects were observed to affect both ear length and ear diameter. According to the combined analysis, ear length was significantly affected by $\mathrm{C} \times \mathrm{N}$ and $\mathrm{P} \times \mathrm{N}$ interactions (Tables 2-a and 2-b). Ear diameter was significantly affected only by $\mathrm{C} \times \mathrm{N}$ interaction (Table 2-c). Regarding ear length (Table 2-a) it was significantly increased by adding $80 \mathrm{~kg}$ $\mathrm{N} /$ fad when maize was grown after berseem, while the further increase in $\mathrm{N}$ level to $120 \mathrm{~kg} \mathrm{~N} /$ fad brought significant increase in ear length of maize grown after wheat. The response equation predicated possible maximization of ear length to 18.49 and $18.79 \mathrm{~cm}$ due to predicated maximum additions of 50.73 and $100 \mathrm{~kg} \mathrm{~N} / \mathrm{fad}$, respectively. These results are quite interesting as they clearly indicate the need of lower $\mathrm{N}$ level in order to maximize ear length after berseem than after wheat. These results refer to more availability of $\mathrm{N}$ in fields of berseem than fields of wheat (Table 1-a). This effect was observed in ear diameter (Table 2-c) but, further indicate more need of $\mathrm{N}$ up to $153.3 \mathrm{~kg} \mathrm{~N} / \mathrm{fad}$ after wheat compared with only $53.33 \mathrm{~kg} \mathrm{~N} /$ fad after berseem. Ear length was also affected by the $\mathrm{N} \times \mathrm{P}$ interaction as shown in Table (2-b). In the check $\mathrm{P}$ plots, each $\mathrm{N}$ increment produced a significant increase in ear length, however, in the P fertilized plots with either P levels, no significant increase in ear length could be detected beyond the addition of $80 \mathrm{~kg} \mathrm{~N} /$ fad. This effect was clearly indicted by the response equations, where the predicted $\mathrm{N}$ level which could have been used to maximize ear length was consistently decreased as the level of $\mathrm{P}$ fertilization was increased. It seems possible that added $\mathrm{P}$ and its level increase might have had made $\mathrm{N}$ more available to maize plants. This effect could be physiological effect due to the role of $\mathrm{P}$ in enhancing root multiplication and extension and hence more root ramification and thereby more $\mathrm{N}$ availability for uptake. Therefore, the higher the $\mathrm{P}$ level, the lower $\mathrm{N}$ level needed to maximize ear length.

TABLE 2-a. Ear length (cm) of maize as affected by preceding crop treatments and

\begin{tabular}{|c|c|c|c|c|c|c|}
\hline \multirow[b]{2}{*}{$\begin{array}{l}\text { Preceding crop } \\
\text { treatments }\end{array}$} & \multicolumn{3}{|c|}{$\mathrm{N}$ level } & \multirow[b]{2}{*}{$\hat{\mathbf{Y}}=\mathbf{a}+\mathbf{b x}-\mathbf{c} \mathbf{x}^{2}$} & \multirow[b]{2}{*}{$\underline{\hat{\mathbf{Y}}}_{\mathbf{m a x}}$} & \multirow{2}{*}{$\begin{array}{c}\underline{\mathbf{X}}_{\max } \\
\mathbf{k g ~ N} \\
\text { fad }\end{array}$} \\
\hline & $\begin{array}{l}40 \mathrm{~kg} \\
\mathrm{~N} / \mathrm{fad}\end{array}$ & $\begin{array}{c}80 \mathrm{~kg} \\
\mathrm{~N} / \mathrm{fad}\end{array}$ & $\begin{array}{l}120 \mathrm{~kg} \\
\mathrm{~N} / \mathrm{fad}\end{array}$ & & & \\
\hline \multirow{2}{*}{ Berseem } & $\mathrm{B}$ & A & A & \multirow{2}{*}{$17.17+2.08 x-0.82 x^{2}$} & \multirow{2}{*}{18.49} & \multirow{2}{*}{50.73} \\
\hline & $17.17 \mathrm{a}$ & $18.43 \mathrm{a}$ & $18.05 \mathrm{~b}$ & & & \\
\hline \multirow{2}{*}{ Wheat } & $\mathrm{C}$ & B & A & \multirow{2}{*}{$16.48+1.85 x-0.37 x^{2}$} & \multirow{2}{*}{18.79} & \multirow{2}{*}{100.0} \\
\hline & $16.48 \mathrm{~b}$ & $17.96 \mathrm{~b}$ & $18.70 \mathrm{a}$ & & & \\
\hline
\end{tabular}

$\hat{\mathrm{Y}}_{\text {max }}$ : predicted maximum average $\quad \mathrm{X}_{\max }$ : predicted maximum $\mathrm{N}$ level 
TABLE 2-b. Ear length (cm) of maize as affected by $P$ level and $N$ level interaction (combined data).

\begin{tabular}{|c|c|c|c|c|c|c|}
\hline \multirow[b]{2}{*}{ P level } & \multicolumn{3}{|c|}{ N level } & \multirow[b]{2}{*}{$\hat{\mathbf{Y}}=\mathbf{a}+\mathbf{b x}-\mathbf{c} \mathbf{x}^{2}$} & \multirow[b]{2}{*}{$\frac{\hat{\mathbf{Y}}_{\max }}{(\mathbf{c m})}$} & \multirow{2}{*}{$\begin{array}{c}\underline{X}_{\max } \\
\text { kg N/ } \\
\text { fad }\end{array}$} \\
\hline & $\begin{array}{c}40 \mathrm{~kg} \\
\mathrm{~N} / \mathrm{fad}\end{array}$ & $\begin{array}{l}80 \mathrm{~kg} \\
\mathrm{~N} / \mathrm{fad}\end{array}$ & $\begin{array}{l}120 \mathrm{~kg} \\
\text { N/ fad }\end{array}$ & & & \\
\hline \multirow{2}{*}{ Check } & $\mathrm{C}$ & $\mathrm{B}$ & $\mathrm{A}$ & \multirow{2}{*}{$16.03+2.12 x-0.40 x^{2}$} & \multirow{2}{*}{18.79} & \multirow{2}{*}{104.4} \\
\hline & $16.03 \mathrm{~b}$ & $17.74 \mathrm{~b}$ & $18.64 \mathrm{a}$ & & & \\
\hline \multirow{2}{*}{$15.5 \mathrm{~kg} \mathrm{P}_{2} \mathrm{O}_{5} / \mathrm{fad}$} & $\mathrm{B}$ & $\mathrm{A}$ & $\mathrm{A}$ & \multirow{2}{*}{$17.13+2.17 x-0.72 x^{2}$} & \multirow{2}{*}{18.77} & \multirow{2}{*}{60.28} \\
\hline & $17.13 \mathrm{a}$ & $18.58 \mathrm{a}$ & $18.59 \mathrm{ab}$ & & & \\
\hline \multirow{2}{*}{$31 \mathrm{~kg} \mathrm{P}_{2} \mathrm{O}_{5} / \mathrm{fad}$} & $\mathrm{B}$ & $\mathrm{A}$ & $\mathrm{AB}$ & \multirow{2}{*}{$17.32+1.60 x-0.66 x^{2}$} & \multirow{2}{*}{18.29} & \multirow{2}{*}{48.7} \\
\hline & $17.32 \mathrm{a}$ & $18.26 \mathrm{ab}$ & $17.89 \mathrm{~b}$ & & & \\
\hline
\end{tabular}

TABLE 2-c . Ear diameter (cm) of maize as affected by preceding crop treatments and $\mathbf{N}$ level interaction (combined data).

\begin{tabular}{|c|c|c|c|c|c|c|}
\hline \multirow[b]{2}{*}{$\begin{array}{l}\text { Preceding crop } \\
\text { treatments }\end{array}$} & \multicolumn{3}{|c|}{ N level } & \multirow[b]{2}{*}{$\hat{\mathbf{Y}}=\mathbf{a}+\mathbf{b x}-\mathbf{c} \mathbf{x}^{2}$} & \multirow{2}{*}{$\frac{\hat{\mathbf{Y}}_{\max }}{(\mathbf{c m})}$} & \multirow{2}{*}{$\begin{array}{c}\underline{X}_{\max } \\
\text { kg } N / \\
\text { fad }\end{array}$} \\
\hline & $\begin{array}{l}40 \mathrm{~kg} \\
\mathrm{~N} / \mathrm{fad}\end{array}$ & $\begin{array}{l}80 \mathrm{~kg} \\
\mathrm{~N} / \mathrm{fad}\end{array}$ & $\begin{array}{l}120 \mathrm{~kg} \\
\mathrm{~N} / \mathrm{fad}\end{array}$ & & & \\
\hline \multirow{2}{*}{ Berseem } & $\mathrm{A}$ & $\mathrm{A}$ & $\mathrm{A}$ & \multirow{2}{*}{$4.56+0.08 x-0.03 x^{2}$} & \multirow{2}{*}{4.61} & \multirow{2}{*}{53.33} \\
\hline & $4.56 \mathrm{a}$ & $4.61 \mathrm{a}$ & $4.60 \mathrm{a}$ & & & \\
\hline \multirow{2}{*}{ Wheat } & $\mathrm{C}$ & $\mathrm{B}$ & $\mathrm{A}$ & \multirow{2}{*}{$4.27+0.12 x-0.02 x^{2}$} & \multirow{2}{*}{4.49} & \multirow{2}{*}{153.3} \\
\hline & $4.27 \mathrm{~b}$ & $4.37 \mathrm{~b}$ & $4.44 \mathrm{~b}$ & & & \\
\hline
\end{tabular}

$\hat{\mathrm{Y}}_{\text {max }}$ : predicted maximum average $\quad \mathrm{X}_{\text {max }}$ : predicted maximum $\mathrm{N}$ level

\section{Number of grains per ear}

Preceding crop effect: The preceding crop did not reflect any significant effect on number of rows per ear, number of grain per row and hence the number of grains per ear. This was observed in the two seasons and their combined (Table 3). These results refer to similar grain set per ear as ear length and ear diameter were not significantly affected by varying the preceding crop though ear diameter was significantly thicker after berseem than after wheat as was detected by the combined analysis (Table 2). These results are not in accordance with those reported by Bagayako et al. (2000) and Yusuf et al. (2009) and Zivorad et al. (2013) as they reported that, cropping sequence with legume crops might reduce mineral fertilizer requirements of succeeding non- legume crops and increase crop yield.

Phosphorus level effect: In both seasons and their combined analysis, the number of rows per ear was not significantly increased due to the increase of $\mathrm{P}$ level. However, the combined analysis detected significant increase in number of grains per row due to the addition of the first $\mathrm{P}$ increment. This was reflected in number of grains per ear was observed in the first season and the combined analysis (Table 3). These results indicate that, the increase of ear length and diameter due to the increase of $\mathrm{P}$ level (Table 2) was reflected in number of grains per row and hence number of grains per ear but only due to the addition of the first $\mathrm{P}$ increment, where the further increase of $\mathrm{P}$ level did not add any significant increase to the number of grains per row or per ear. Similar results were reported by Mazengia (2011), who showed that, mineral P fertilization was without any significant effect on maize yield attributes. But, these results are not in accordance with those reported by Hegazy et al. (1996), Salem (2000), Hussein (2009), Masood et al. (2011), Omar (2014) and Abd El-Rheem et al. (2015).

Egypt. J. Agron.38, 2 (2016) 


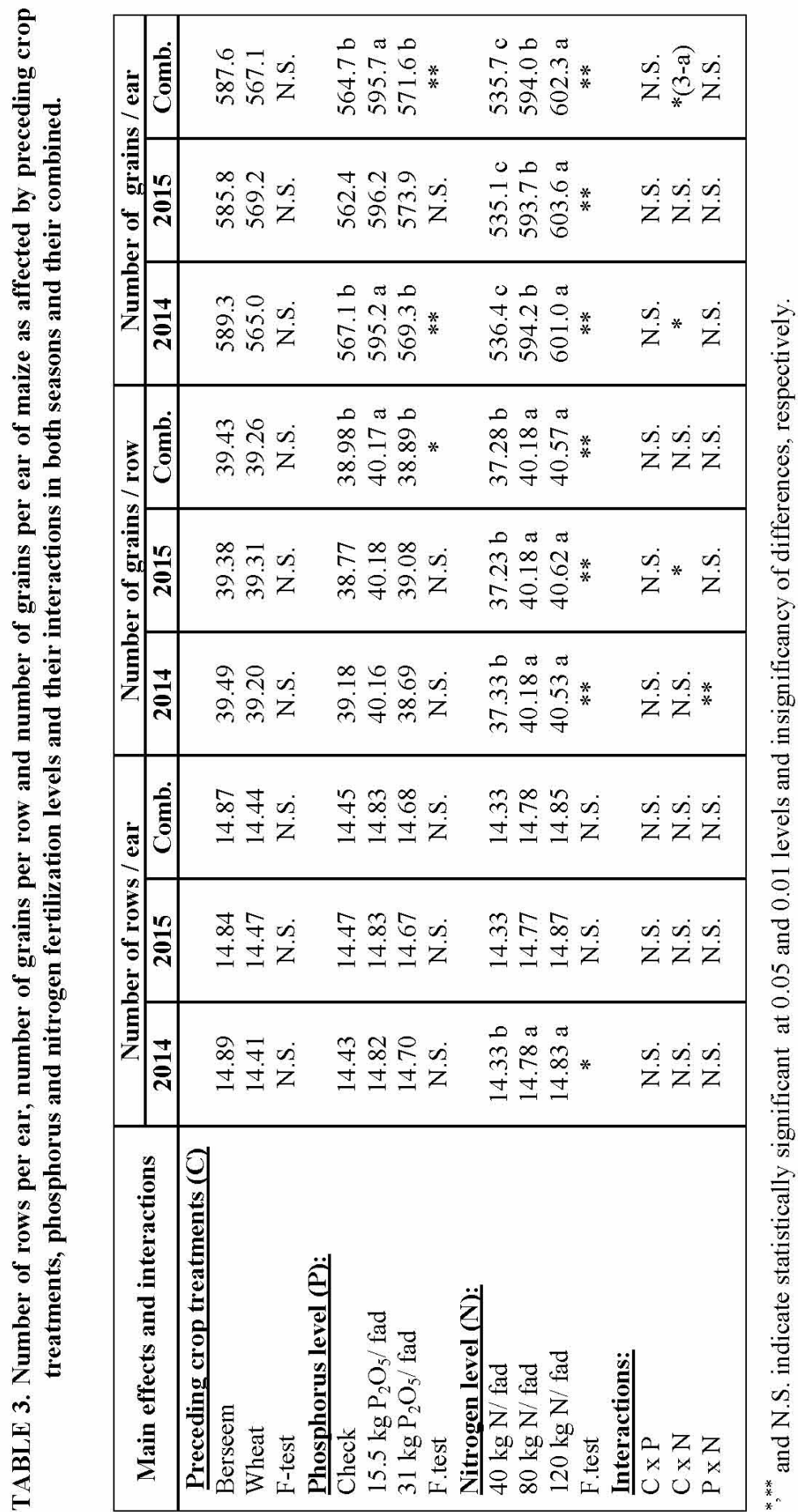

Egypt. J. Agron.38, No. 2 (2016) 
Nitrogen level effect:The first $\mathrm{N}$ increment resulted in a significant increase in each of rows number per ear and number of grains per row. However, number of grains per ear continued to increase significantly due to each $\mathrm{N}$ increase up to the addition of $120 \mathrm{~kg} \mathrm{~N} /$ fad (Table 3). This could be attributed to the increase of ear diameter which was significantly increased with each increase in $\mathrm{N}$ level (Table 2). These results are in harmony with those obtained by Shams (2000), ElMurshedy (2002), Soliman \& Gharib (2011), El-Azab (2012), Kandil (2013) and Mahama et al. (2016).

Interaction effect: The combined analysis detected significant $\mathrm{C} \times \mathrm{N}$ interaction in number of grains per ear as shown in Table (3-a). It is quite clear that number of grains per ear continued to increase significantly up to the addition of $120 \mathrm{~kg} \mathrm{~N} /$ fad after wheat, but failed to increase significantly beyond the addition of $80 \mathrm{~kg} \mathrm{~N} /$ fad after berseem. This effect was observed in the both ear length (Table 2-a) and as well as in ear diameter (Table 2-c) and hence could account for the results obtained herein regarding the number of grains per ear. These results were formerly discussed and obviously cleared that, the soil of the experiment site after berseem was more enriched by available soil $\mathrm{N}$ (Table 1-a) which in turn saved the use of mineral $\mathrm{N}$ as indicated by the response equations where only $51.13 \mathrm{~kg} \mathrm{~N} /$ fad were needed to maximize the number of grains of ear to 611.9 grain after berseem compared with $96.06 \mathrm{~kg} \mathrm{~N} /$ fad needed to maximize this number to 612.5 grain after wheat.

TABLE 3-a. Number of grains per ear of maize as affected by preceding crop treatments and $\mathrm{N}$ level interaction (combined data).

\begin{tabular}{|c|c|c|c|c|c|c|}
\hline \multirow{2}{*}{$\begin{array}{l}\text { Preceding } \\
\text { crop } \\
\text { treatments }\end{array}$} & \multicolumn{3}{|c|}{ N level } & \multirow[b]{2}{*}{$\hat{\mathbf{Y}}=\mathbf{a}+\mathbf{b x}-\mathbf{c} \mathbf{x}^{2}$} & \multirow{2}{*}{$\frac{\hat{\mathbf{Y}}_{\max }}{(\mathbf{N o .})}$} & \multirow{2}{*}{$\begin{array}{c}\underline{X}_{\max } \\
\mathbf{k g ~ N} / \\
\text { fad }\end{array}$} \\
\hline & $\begin{array}{l}40 \mathrm{~kg} \\
\mathrm{~N} / \mathrm{fad}\end{array}$ & $\begin{array}{l}80 \mathrm{~kg} \\
\mathrm{~N} / \mathrm{fad}\end{array}$ & $\begin{array}{l}120 \mathrm{~kg} \\
\mathrm{~N} / \mathrm{fad}\end{array}$ & & & \\
\hline \multirow{2}{*}{ Berseem } & $B$ & $\mathrm{~A}$ & $\mathrm{~A}$ & \multirow{2}{*}{$558.5+83.6 x-32.7 x^{2}$} & \multirow{2}{*}{611.9} & \multirow{2}{*}{51.13} \\
\hline & $558.5 \mathrm{a}$ & $609.4 \mathrm{a}$ & $594.9 \mathrm{a}$ & & & \\
\hline \multirow{2}{*}{ Wheat } & $\mathrm{C}$ & $\mathrm{B}$ & $\mathrm{A}$ & \multirow{2}{*}{$513.0+82.9 x-17.3 x^{2}$} & \multirow{2}{*}{612.5} & \multirow{2}{*}{96.06} \\
\hline & $513.0 \mathrm{~b}$ & $578.6 \mathrm{a}$ & $609.7 \mathrm{a}$ & & & \\
\hline
\end{tabular}

Grain weight and grain yield per fad

Preceding crop effect: In the first season and the combined analysis of both seasons, the seed index and shelling percentage were significantly increased after berseem compared with these traits averages after wheat. This was in turn reflected in the grain weight per ear and finally in the grain yield per fad as indicated by the combined analysis (Table 4). These results could be attributed to the increase of seed index and shelling percentage as neither the ear length and diameter (Table 2) or the number of grains per ear (Table 3) was increased significantly due to growing maize after berseem. The data further indicated that, the favorable effect of berseem was gained by maize during their grain filling rather than earlier during grain set where the number of grains per ear did not vary significantly due to varying the preceding crop. Similar results were reported by Yusuf et al. (2009) and Zivorad et al. (2013). 


\begin{tabular}{|c|c|c|c|c|c|c|c|}
\hline 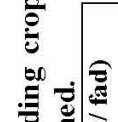 & 㝘 & 占 & 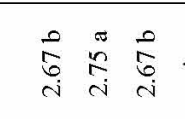 & & $\begin{array}{ccc}0 & 0 & \sigma \\
\stackrel{f}{f} & \vec{\infty} & \infty \\
i & \infty & c \\
j & i\end{array}$ & $\stackrel{*}{*}$ & 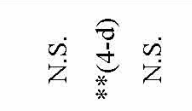 \\
\hline 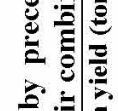 & กै: & 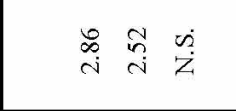 & 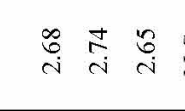 & $\stackrel{\ddot{n}}{\ddot{Z}}$ & 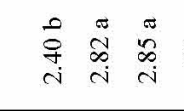 & * & $\begin{array}{lll}\dot{n} & \dot{n} & \dot{M} \\
\dot{Z} & \ddot{Z} & \ddot{Z}\end{array}$ \\
\hline 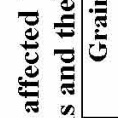 & ث̦ & 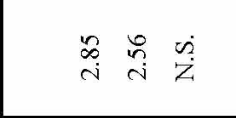 & 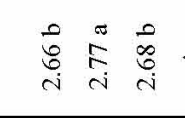 & * & 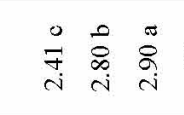 & * & $\stackrel{*}{*} * \begin{array}{c}\dot{\rho} \\
\ddot{Z}\end{array}$ \\
\hline 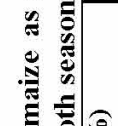 & ثิ & $\begin{array}{l}\text { 둔 } \\
\text { N } \\
\infty\end{array}$ & 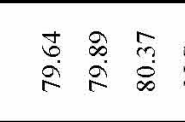 & $\dot{\vec{z}}$ & 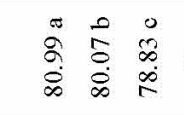 & * & $\dot{\Delta} \dot{z} \dot{z} \dot{z}$ \\
\hline 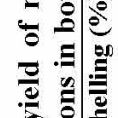 & 象 & 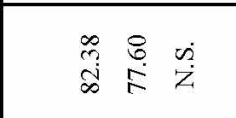 & 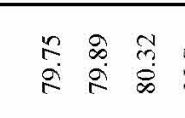 & $\dot{\dot{a}}$ & 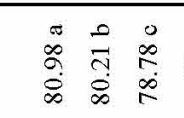 & $*$ & $\begin{array}{lll}\dot{\Delta} & \dot{n} & \dot{\lambda} \\
\dot{z} & \dot{z} & \end{array}$ \\
\hline 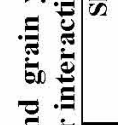 & $\overrightarrow{\bar{n}}$ & $\underset{\infty}{\vec{D}} \stackrel{\overrightarrow{1}}{E} *$ & 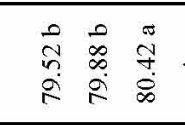 & $*$ & 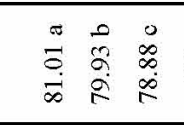 & * & 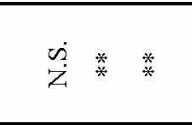 \\
\hline 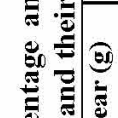 & ثิ) & 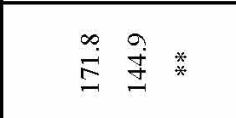 & 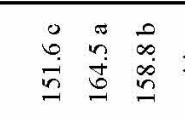 & * & 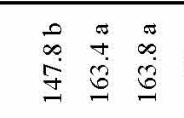 & * & 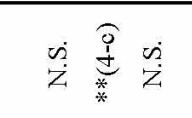 \\
\hline 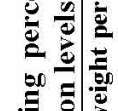 & 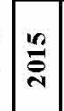 & 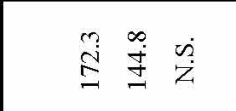 & 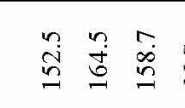 & $\dot{\ddot{n}}$ & 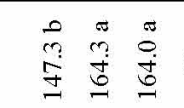 & 羍 & $\begin{array}{lll}\dot{n} & \dot{n} & \dot{n} \\
\dot{z} & \ddot{z} & \ddot{z}\end{array}$ \\
\hline ปั & تัخ & 愛主* & 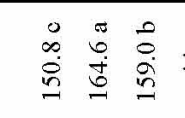 & * & \begin{tabular}{lll}
0 & 0 & $\pi$ \\
$m$ & $n$ & $n$ \\
$\infty$ & 0 & 0 \\
\hdashline & 0 & 0
\end{tabular} & * & $\stackrel{\dot{\nu}}{*} \stackrel{*}{*} *$ \\
\hline נ) & ث) & 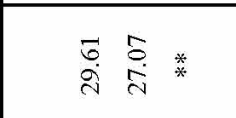 & $\begin{array}{lll}0 & \pi & 0 \\
0 & \infty & = \\
0 & \infty & = \\
\infty & \infty & \infty \\
\sim & \infty & \sim\end{array}$ & ** & 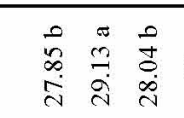 & * & 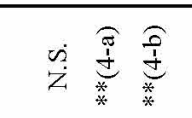 \\
\hline 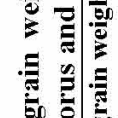 & 空 & 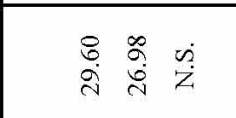 & 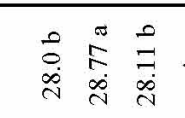 & * & 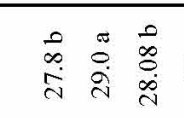 & \% & $\stackrel{\dot{2}}{\stackrel{2}{z}} *$ \\
\hline है & जे & 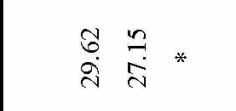 & 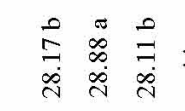 & * & 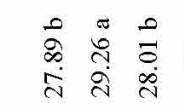 & * & $*$ * \\
\hline 吾 & 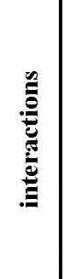 & 氧 & 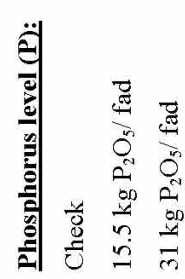 & 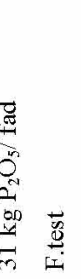 & 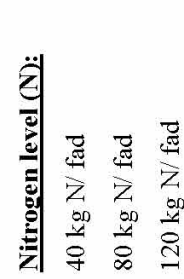 & $\sum_{\substack{0 \\
0.00}}$ & 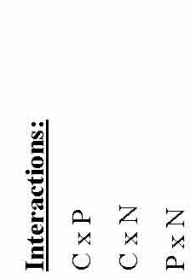 \\
\hline
\end{tabular}

Egypt. J. Agron.38, No. 2 (2016) 
Phosphorus level effect: Addition of the first $\mathrm{P}$ increment recorded the highest averages of grain yield per fad as well as 100-grain weight and grain weight per ear (Table 4). However, the highest shelling percentage was obtained due to the addition of the highest $\mathrm{P}$ level as indicated by a significant effect in only the first season. Similar significant effects were observed in all yield attributes as observed in Tables 2 and 3. These results are in harmony with those obtained by Salem (2000), Saleem et al. (2003), Hussein (2009), Masood et al. (2011), Omar (2014) and Abd El-Rheem et al. (2015).

Nitrogen level effect: The first $\mathrm{N}$ increment produced significant increase in grain yield attributes but, the combined analysis detected consistent significant increase in grain yield/ fad due to each $\mathrm{N}$ increment up to the addition of $120 \mathrm{~kg}$ $\mathrm{N} / \mathrm{fad}$ reflecting the trend observed in the first season (Table 4). Similar significant effects were reported by El-Murshedy (2002), Soliman \& Gharib (2011), El-Azab (2012), Kandil (2013) and Mahama et al. (2016).

Interaction effect: Significant interaction effects were detected to affect the grain yield/ fad and some of its attributes in both seasons. The combined analysis indicated clear significant interaction effect between the preceding crop and $\mathrm{N}$ levels as observed in grain yield per fad and all of its attributes. As far as the effect of $\mathrm{C} \times \mathrm{N}$ interaction on grain yield per fad (Table 4-d) and Fig.1, the first $\mathrm{N}$ increment was quite enough to increase the yield average after berseem, but the second $\mathrm{N}$ increment was still badly needed to maximize this average after wheat. The response equations showed diminishing increase in grain yield with increasing $\mathrm{N}$ level after berseem or after wheat. However, these quadratic equations detected maximum $\mathrm{N}$ levels of $105.7 \mathrm{~kg} \mathrm{~N} /$ fad after wheat compared with only $50.83 \mathrm{~kg} \mathrm{~N} / \mathrm{fad}$ after berseem in order to maximize yield averages to 2.89 and $3.03 \mathrm{ton} / \mathrm{fad}$, respectively.

These effects were also observed in seed index, grain weight per ear as shown in Tables (4-a) and (4-c), respectively. Seed index was significantly affected by the N x P interaction (Table 4-b) where no particular trend could be detected from these results as higher predicted $\mathrm{N}$ levels were needed when the level of $\mathrm{P}$ was increased in order to maximize seed index to lower averages. According to these results, and in particular the grain yield per fad the only significant interaction was that between the preceding crop and $\mathrm{N}$ level which clearly indicate an increase in soil fertility level, most probably from available $\mathrm{N}$, where about $50 \%$ of $\mathrm{N}$ level could be saved when maize was preceded by berseem than by wheat (Table 4-d). Veenstra et al. (2007) showed that, winter legume cover crops can improve physical soil properties, reduce soil erosion, conserve soil water, recycle plant nutrients, and increase crop yield potential and soil productivity. 
TABLE 4-a. 100-grain weight (g) of maize as affected by preceding crop treatments and $\mathrm{N}$ level interaction (combined data).

\begin{tabular}{|c|c|c|c|c|c|c|}
\hline \multirow{2}{*}{$\begin{array}{l}\text { Preceding crop } \\
\text { treatments }\end{array}$} & \multicolumn{3}{|c|}{ N level } & \multirow[b]{2}{*}{$\hat{\mathbf{Y}}=\mathbf{a}+\mathbf{b x}-\mathbf{c} \mathbf{x}^{2}$} & \multirow{2}{*}{$\frac{\hat{\hat{\mathbf{Y}}}_{\max }}{(\mathbf{g})}$} & \multirow{2}{*}{$\begin{array}{c}\underline{X}_{\max } \\
\text { kg } \\
\text { fad }\end{array}$} \\
\hline & $\begin{array}{l}40 \mathrm{~kg} \\
\mathrm{~N} / \mathrm{fad}\end{array}$ & $\begin{array}{c}80 \mathrm{~kg} \\
\mathrm{~N} / \mathrm{fad}\end{array}$ & \begin{tabular}{|l|}
$120 \mathrm{~kg}$ \\
$\mathrm{~N} / \mathrm{fad}$
\end{tabular} & & & \\
\hline \multirow{2}{*}{ Berseem } & $\mathrm{A}$ & $\mathrm{A}$ & $\mathrm{B}$ & \multirow{2}{*}{$29.93+1.48 x-1.08 x^{2}$} & \multirow{2}{*}{30.44} & \multirow{2}{*}{27.44} \\
\hline & $29.93 \mathrm{a}$ & $30.33 \mathrm{a}$ & $28.58 \mathrm{a}$ & & & \\
\hline \multirow{2}{*}{ Wheat } & $\mathrm{B}$ & $\mathrm{A}$ & $\mathrm{A}$ & \multirow{2}{*}{$25.77+3.45 x-1.29 x^{2}$} & \multirow{2}{*}{28.08} & \multirow{2}{*}{53.49} \\
\hline & $25.77 \mathrm{~b}$ & $27.93 \mathrm{~b}$ & $27.51 \mathrm{~b}$ & & & \\
\hline
\end{tabular}

$\hat{\mathrm{Y}}_{\max }$ : predicted maximum average

$\mathrm{X}_{\max }:$ predicted maximum $\mathrm{N}$ level

TABLE 4-b. 100-grain weight (g) of maize as affected by $P$ level and $N$ level interaction (combined data).

\begin{tabular}{|c|c|c|c|c|c|c|}
\hline \multirow[b]{2}{*}{ P level } & \multicolumn{3}{|c|}{$\mathbf{N}$ level } & \multirow[b]{2}{*}{$\hat{\mathbf{Y}}=\mathbf{a}+\mathbf{b x}-\mathbf{c} \mathbf{x}^{2}$} & \multirow[b]{2}{*}{$\underline{\hat{\mathbf{Y}}}_{(\mathbf{m a x}}$} & \multirow{2}{*}{$\begin{array}{c}\underline{X}_{\max } \\
\text { fad }\end{array}$} \\
\hline & $\begin{array}{l}40 \mathrm{~kg} \\
\mathrm{~N} / \mathrm{fad}\end{array}$ & $\begin{array}{c}80 \text { kg } \\
\text { N/ fad }\end{array}$ & $\begin{array}{l}120 \mathrm{~kg} \\
\mathrm{~N} / \mathrm{fad}\end{array}$ & & & \\
\hline \multirow{2}{*}{ Check } & $\mathrm{B}$ & $\mathrm{A}$ & B & \multirow{2}{*}{$27.33+3.42 x-1.6 x^{2}$} & \multirow{2}{*}{29.16} & \multirow{2}{*}{42.75} \\
\hline & $27.33 \mathrm{~b}$ & $29.15 b$ & $27.77 \mathrm{a}$ & & & \\
\hline \multirow{2}{*}{$\begin{array}{l}15.5 \mathrm{~kg} \\
\mathrm{P}_{2} \mathrm{O}_{5} / \text { fad }\end{array}$} & $\mathrm{B}$ & $\mathrm{A}$ & $\mathrm{B}$ & \multirow{2}{*}{$27.89+4.6 x-2.2 x^{2}$} & \multirow{2}{*}{30.29} & \multirow{2}{*}{41.87} \\
\hline & $27.89 \mathrm{ab}$ & $30.29 \mathrm{a}$ & $28.30 \mathrm{a}$ & & & \\
\hline \multirow{2}{*}{$\begin{array}{l}31 \mathrm{~kg} \\
\mathrm{P}_{2} \mathrm{O}_{5} / \text { fad }\end{array}$} & $\mathrm{A}$ & $\mathrm{A}$ & $\mathrm{A}$ & \multirow{2}{*}{$28.32+0.61 x-0.24 x^{2}$} & \multirow{2}{*}{27.93} & \multirow{2}{*}{50.83} \\
\hline & $28.32 \mathrm{a}$ & $27.95 \mathrm{c}$ & $28.06 \mathrm{a}$ & & & \\
\hline
\end{tabular}

$\hat{\mathrm{Y}}_{\max }$ : predicted maximum average $\quad \mathrm{X}_{\max }$ : predicted maximum $\mathrm{N}$ level

TABLE 4-c. Grain weight per ear (g) of maize as affected by preceding crop treatments and $\mathrm{N}$ level interaction (combined data).

\begin{tabular}{|c|c|c|c|c|c|c|}
\hline \multirow{2}{*}{$\begin{array}{l}\text { Preceding } \\
\text { crop } \\
\text { treatments }\end{array}$} & \multicolumn{3}{|c|}{$\mathbf{N}$ level } & \multirow[b]{2}{*}{$\hat{\mathbf{Y}}=\mathbf{a}+\mathbf{b x}-\mathbf{c} \mathbf{x}^{2}$} & \multirow[b]{2}{*}{$\underline{\hat{\mathbf{Y}}}_{\frac{\max }{(\mathbf{g})}}$} & \multirow{2}{*}{$\begin{array}{c}\underline{X}_{\max } \\
\mathbf{k g ~ N} / \\
\text { fad }\end{array}$} \\
\hline & $\begin{array}{l}40 \mathrm{~kg} \\
\mathrm{~N} / \mathrm{fad}\end{array}$ & $\begin{array}{l}80 \mathrm{~kg} \\
\mathrm{~N} / \mathrm{fad}\end{array}$ & $\begin{array}{l}120 \mathrm{~kg} \\
\mathrm{~N} / \mathrm{fad}\end{array}$ & & & \\
\hline \multirow{2}{*}{ Berseem } & $\mathrm{B}$ & $\mathrm{A}$ & $\mathrm{AB}$ & \multirow{2}{*}{$166.7+19.8 x-8.8 x^{2}$} & \multirow{2}{*}{177.8} & \multirow{2}{*}{45.0} \\
\hline & $166.7 \mathrm{a}$ & $177.7 \mathrm{a}$ & $171.1 \mathrm{a}$ & & & \\
\hline \multirow{2}{*}{ Wheat } & $\mathrm{B}$ & $\mathrm{A}$ & $\mathrm{A}$ & \multirow{2}{*}{$129.0+26.7 x-6.5 x^{2}$} & \multirow{2}{*}{156.4} & \multirow{2}{*}{82.15} \\
\hline & $129.0 \mathrm{~b}$ & $149.2 \mathrm{~b}$ & $156.4 \mathrm{~b}$ & & & \\
\hline
\end{tabular}

$\hat{\mathrm{Y}}_{\max }$ : predicted maximum average

$\mathrm{X}_{\max }$ : predicted maximum $\mathrm{N}$ level

TABLE 4-d. Grain yield (ton/ fad) of maize as affected by preceding crop treatments and $\mathbf{N}$ level interaction (combined data).

\begin{tabular}{|c|c|c|c|c|c|c|}
\hline \multirow[b]{2}{*}{$\begin{array}{l}\text { Preceding crop } \\
\text { treatments }\end{array}$} & \multicolumn{3}{|c|}{$\mathbf{N}$ level } & \multirow[b]{2}{*}{$\hat{\mathbf{Y}}=\mathbf{a}+\mathbf{b x}-\mathbf{c} \mathbf{x}^{2}$} & \multirow[b]{2}{*}{$\begin{array}{l}\hat{\underline{Y}}_{\max } \\
\text { ton/ } \\
\text { fad }\end{array}$} & \multirow[b]{2}{*}{$\begin{array}{c}\underline{X}_{\max } \\
\text { kg N/ } \\
\text { fad }\end{array}$} \\
\hline & $\begin{array}{l}40 \mathrm{~kg} \\
\mathrm{~N} / \mathrm{fad}\end{array}$ & $\begin{array}{l}80 \mathrm{~kg} \\
\mathrm{~N} / \mathrm{fad}\end{array}$ & $\begin{array}{c}120 \\
\mathrm{~kg} \mathrm{~N} / \\
\text { fad }\end{array}$ & & & \\
\hline \multirow{2}{*}{ Berseem } & B & $\mathrm{A}$ & $\mathrm{A}$ & \multirow{2}{*}{$2.64+0.61 x-0.24 x^{2}$} & \multirow{2}{*}{3.03} & \multirow{2}{*}{50.83} \\
\hline & $2.64 \mathrm{a}$ & $3.01 \mathrm{a}$ & $2.90 \mathrm{a}$ & & & \\
\hline \multirow{2}{*}{ Wheat } & $\mathrm{C}$ & B & A & \multirow{2}{*}{$2.16+0.56 x-0.11 x^{2}$} & \multirow{2}{*}{2.89} & \multirow{2}{*}{105.7} \\
\hline & $2.16 \mathrm{~b}$ & $2.61 \mathrm{~b}$ & $2.85 \mathrm{a}$ & & & \\
\hline
\end{tabular}

$\hat{\mathrm{Y}}_{\max }$ : predicted maximum average $\quad \mathrm{X}_{\max }$ : predicted maximum $\mathrm{N}$ level 


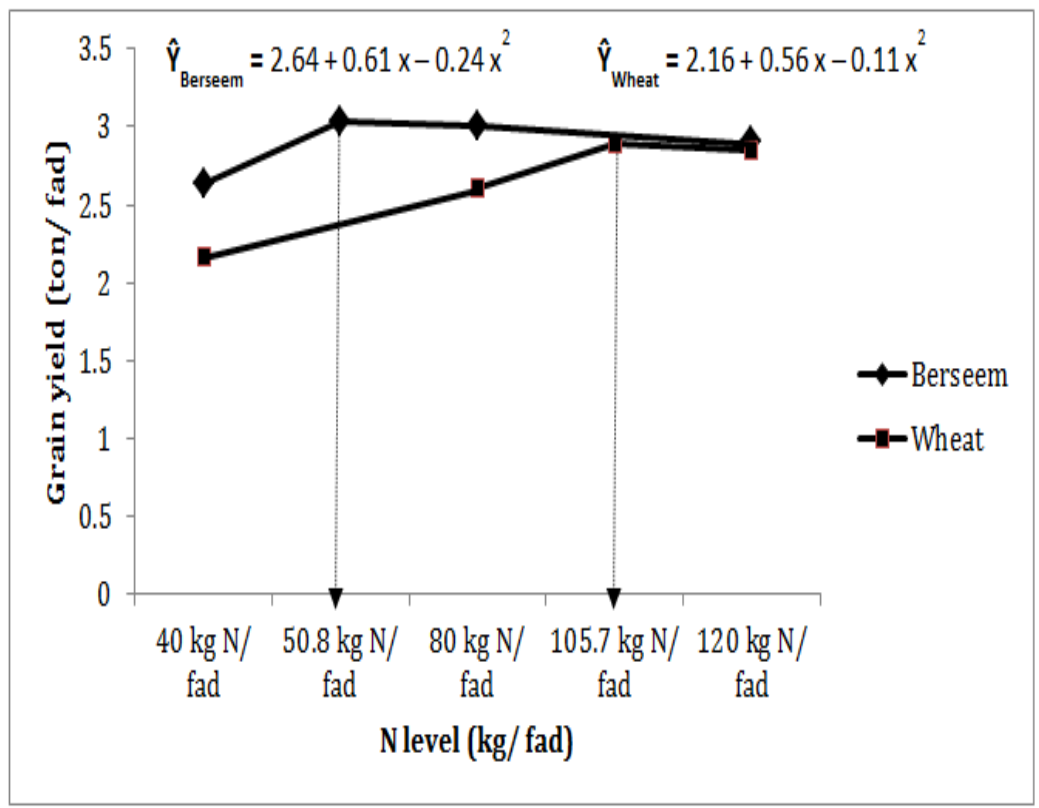

Fig. 1. Respone of maize yield (ton/ fad) to the interaction effect between preceding crop and $\mathbf{N}$ fertililzation level (combined data)

Ears, stover and total yields and harvest index

Preceding crop effect: The preceding crop was without significant effect on ears and total yields per fad, however, the combined analysis showed that, the ears yield per fad was significantly increased after berseem compared with that after wheat (Table 5). In the first season and the combined analysis, stover yield was higher after wheat compared with after berseem. Therefore, harvest index was higher after berseem compared with after wheat. These results are in accordance with those reported by Bagayako et al. (2000) and Yusuf et al. (2009) and Zivorad et al. (2013).

Phosphorus level effect: In the first season and the combined analysis of both seasons, ear and stover as well as total yield per fad were increased due to the addition of the first $\mathrm{P}$ increment, but, the second increment failed to add a further significant increase (Table 5). However, in both seasons and their combined analysis, harvest index was not significantly increased due to the increase of $\mathrm{P}$ level. The failure of the second $\mathrm{P}$ increment to increase either the grain or stover yield per fad was observed also in all yield attributes (Tables 2-4) and could be attributed to the high soil fertility level from P after berseem (Table 1-a). Similar significant effects were reported by Saleem et al. (2003), Hussein (2009), Masood et al. (2011), Omar (2014) and Abd El-Rheem et al. (2015). 


\begin{tabular}{|c|c|c|c|c|c|c|c|c|c|c|c|c|}
\hline 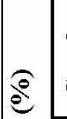 & है & & $\begin{array}{c}0 \\
\substack{n \\
m}\end{array}$ & & 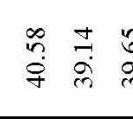 & $\begin{array}{l}n \\
\stackrel{0}{c} \\
\dot{m}\end{array}$ & & $\begin{array}{ll}\pi & 0 \\
0 & 0 \\
0 & 0 \\
\Rightarrow & 0\end{array}$ & $\begin{array}{l}0 \\
0 \\
0 \\
0 \\
2\end{array}$ & & * & $\begin{array}{lll}\dot{n} & \dot{n} \\
\dot{z} & \dot{z} \\
\dot{z}\end{array}$ \\
\hline 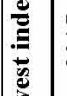 & 突 & & $\underset{\substack{\infty \\
\infty}}{\stackrel{\infty}{\infty}}$ & $\dot{n}$ & 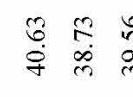 & $\begin{array}{l}\stackrel{0}{n} \\
\text { di } \\
\text { m. }\end{array}$ & $\dot{z}$ & 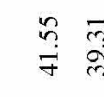 & $\overrightarrow{3}$ & & $\dot{\nu}$ & \begin{tabular}{lll}
$\dot{n}$ & $\dot{n}$ & $\dot{n}$ \\
$\dot{z}$ & $\ddot{z}$ & \multicolumn{2}{c}{}
\end{tabular} \\
\hline Е & 氙 & 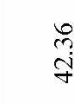 & $\frac{n}{n}$ & * & 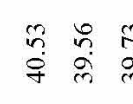 & $\stackrel{m}{\stackrel{m}{m}}$ & 官 & 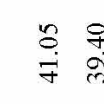 & 导 & & غ. & $\begin{array}{ll}\dot{n} \\
\dot{z}\end{array}$ \\
\hline छे & ठิ & & {$\left[\begin{array}{l}\infty \\
\infty \\
0\end{array}\right.$} & & $\begin{array}{l}0 \\
\vec{b} \\
\dot{0}\end{array}$ & 芦 & * & $\begin{array}{l}0 \\
\infty \\
\infty \\
i\end{array}$ & $\stackrel{0}{2}$ & & * & 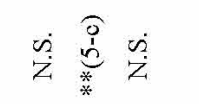 \\
\hline 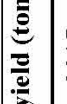 & 离 & $\begin{array}{c}\infty \\
\infty \\
0 \\
0\end{array}$ & के & $\dot{\bar{z}}$ & 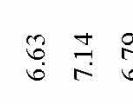 & શे & $\ddot{z}$ & 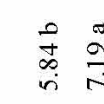 & 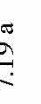 & & * & * 离离 \\
\hline है & ت্ं & & {$\left[\begin{array}{l}\infty \\
\infty \\
0\end{array}\right.$} & $\dot{n}$ & 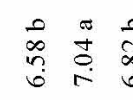 & $\underset{\substack{0 \\
0 \\
0 \\
0}}{0}$ & * & $\begin{array}{c}0 \\
\stackrel{2}{0} \\
\text { in }\end{array}$ & tis & $\frac{8}{2}$ & * & 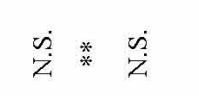 \\
\hline$\widehat{\Xi}$ & نे & 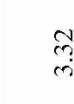 & 8 & $\stackrel{*}{*}$ & 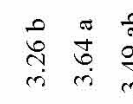 & $\begin{array}{l}\text { कै } \\
\text { कू } \\
\text { के }\end{array}$ & * & ते & 离 & $\pi$ & * & 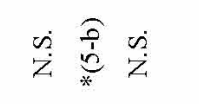 \\
\hline $\mid$ & 象 & $m$ & $\begin{array}{l}+ \\
0 \\
i\end{array}$ & $\dot{\vec{\Delta}}$ & 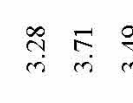 & के & 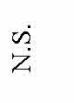 & 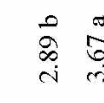 & $\begin{array}{l}\frac{\pi}{6} \\
6 \\
3\end{array}$ & $\sigma$ & * & 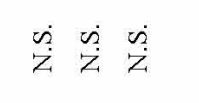 \\
\hline 童 & సे & m & $\begin{array}{l}n \\
i \\
i\end{array}$ & * & 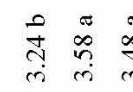 & $\begin{array}{l}\infty \\
\infty \\
\infty \\
\infty \\
\infty\end{array}$ & * & 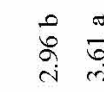 & $\frac{\pi}{6}$ & 2 & * & $\stackrel{*}{*} \stackrel{\ddot{n}}{*}$ \\
\hline छ & 音 & f & ते & * & 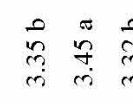 & $\begin{array}{l}\vec{N} \\
\vec{m}\end{array}$ & * & 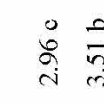 & $\frac{2}{n}$ & $\frac{\pi}{6}$ & * & 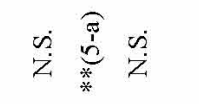 \\
\hline 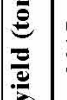 & กั่ & 7 & $\begin{array}{l}n \\
\text { cे } \\
\text { ले }\end{array}$ & $\stackrel{\dot{n}}{\bar{z}}$ & 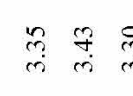 & ले & $\dot{\bar{z}}$ & $\begin{array}{ll}\vec{a} & \approx \\
\dot{\alpha} & \vec{n}\end{array}$ & 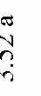 & $v$ & * & $\begin{array}{lll}\dot{\theta} & \dot{\sim} & \dot{z} \\
\dot{z} & \ddot{z}\end{array}$ \\
\hline 离 & Tे & 年 & iे & $\stackrel{\dot{z}}{z}$ & 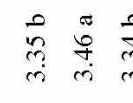 & 孛 & $*$ & $\begin{array}{ll}0 & 0 \\
\vdots & 0 \\
i & 0\end{array}$ & ? & $\infty$ & * & 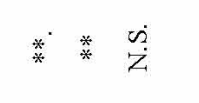 \\
\hline 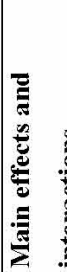 & | & $\begin{array}{ll}0 \\
0\end{array}$ & 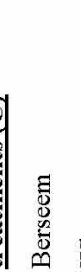 & 嗬 & 朝 & 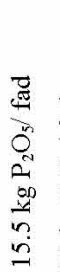 & 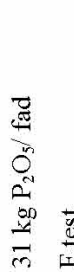 & 兽 & 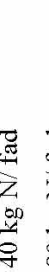 & & 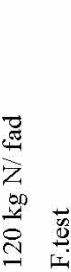 & : \\
\hline
\end{tabular}

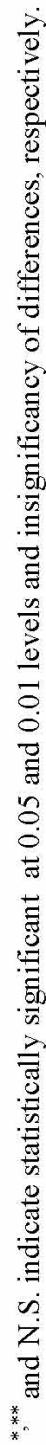

Egypt. J. Agron.38, No. 2 (2016) 
Nitrogen level effect: Each increase in $\mathrm{N}$ level was reflected in a significant increase in ears and total yields per fad up to the addition of 120 $\mathrm{kg} \mathrm{N} / \mathrm{fad}$ in the first season and the combined analysis, but, the second $\mathrm{N}$ increment failed to increase stover yield significantly though it evidently increased the ears yield per fad, possibly due to increase of grain yield per fad (Table 5). However, the combined analysis detected significant decrease in harvest index due to the increase of N level to 80 or $120 \mathrm{~kg} \mathrm{~N} / \mathrm{fad}$ which produced at par significant decrease in harvest index. Similar results were reported by Shams (2000), El-Murshedy (2002), Abd-Alla (2005), Soliman \& Gharib (2011), Darwich (2013), Abd El-Rheem et al. (2015) and Mahama et al. (2016).

Interaction effect: According to the combined analysis ears, stover and total yields per fad were significantly affected by $\mathrm{C} \times \mathrm{N}$ interaction (Tables 5-a, 5-b and 5-c). The ears yield (Table 5-a) and total yield (Table 5-c) continued to increase significantly due to each increase in $\mathrm{N}$ level when maize was preceded by wheat, but, the second $\mathrm{N}$ increment failed to increase it when maize was preceded by berseem. The response equations predicted maximum ears yield of 3.71 and 3.77 ton per fad due to predicted additions of 56.49 and $110.8 \mathrm{~kg} \mathrm{~N} /$ fad, respectively. A look in Table 5-c regarding this interaction effect on total yield per fad showed linearity in the increase of total yield due to the increase of $\mathrm{N}$ level when maize was preceded by wheat, however, quadratic increase when maize was preceded by berseem. The response equations predicted maximum total yield of 7.49 ton per fad due to a predicted addition of $55.56 \mathrm{~kg} \mathrm{~N} / \mathrm{fad}$.

Table 5-b shows the interaction effect of $\mathrm{C} \times \mathrm{N}$ on stover yield/ fad according to the combined analysis. The stover yield failed to increase significantly due to any increase in $\mathrm{N}$ level when maize preceded by berseem, but however, was significantly increased due to the increase of $\mathrm{N}$ level up to $120 \mathrm{~kg} \mathrm{~N}$ per fad when maize was preceded by wheat. Interestingly, the response of stover yield per fad was quadratic after berseem but however linear after wheat where $54.58 \mathrm{~kg} \mathrm{~N} / \mathrm{fad}$ were enough to maximize the stover yield to $3.80 \mathrm{ton} / \mathrm{fad}$ after berseem but however, 120 $\mathrm{kg} \mathrm{N} /$ fad were not yet enough to maximize it after wheat.

Acknowledgement: The author is grateful to Prof. Dr. Ahmed A. Abdul Galil, Professor of Agronomy, Faculty of Agriculture, Zagazig University for his continuous help, valuable suggestions, encouragement and for revising this paper. 
TABLE 5-a. Ears yield (ton/ fad) of maize as affected by preceding crop treatments and $\mathrm{N}$ level interaction (combined data).

\begin{tabular}{|c|c|c|c|c|c|c|}
\hline \multirow[b]{2}{*}{$\begin{array}{l}\text { Preceding crop } \\
\text { treatments }\end{array}$} & \multicolumn{3}{|c|}{ N level } & \multirow[b]{2}{*}{$\hat{\mathbf{Y}}=\mathbf{a}+\mathbf{b x}-\mathbf{c} \mathbf{x}^{2}$} & \multirow[b]{2}{*}{$\begin{array}{l}\underline{\hat{\mathbf{Y}}}_{\max } \\
\text { ton/ } \\
\text { fad }\end{array}$} & \multirow[b]{2}{*}{$\begin{array}{c}\underline{X}_{\max } \\
\text { fad }\end{array}$} \\
\hline & $\begin{array}{l}40 \mathrm{~kg} \\
\mathrm{~N} / \mathrm{fad}\end{array}$ & $\begin{array}{c}80 \mathrm{~kg} \\
\mathrm{~N} / \mathrm{fad}\end{array}$ & $\begin{array}{c}120 \\
\mathrm{~kg} \mathrm{~N} / \\
\text { fad }\end{array}$ & & & \\
\hline \multirow{2}{*}{ Berseem } & $\mathrm{B}$ & A & $\mathrm{A}$ & \multirow{2}{*}{$3.14+0.81 x-0.29 x^{2}$} & \multirow{2}{*}{3.71} & \multirow{2}{*}{56.49} \\
\hline & $3.14 \mathrm{a}$ & $3.66 \mathrm{a}$ & $3.61 \mathrm{a}$ & & & \\
\hline \multirow{2}{*}{ Wheat } & $\mathrm{C}$ & $\mathrm{B}$ & A & \multirow{2}{*}{$2.77+0.72 x-0.13 x^{2}$} & \multirow{2}{*}{3.77} & \multirow{2}{*}{110.8} \\
\hline & $2.77 \mathrm{~b}$ & $3.36 \mathrm{~b}$ & $3.69 \mathrm{a}$ & & & \\
\hline
\end{tabular}

$\hat{\mathrm{Y}}_{\max }$ : predicted maximum average $\quad \mathrm{X}_{\max }$ : predicted maximum $\mathrm{N}$ level

TABLE 5-b. Stover yield (ton/ fad) of maize as affected by preceding crop treatments and

\begin{tabular}{|c|c|c|c|c|c|c|}
\hline \multirow{2}{*}{$\begin{array}{l}\text { Preceding } \\
\text { crop } \\
\text { treatments }\end{array}$} & \multicolumn{3}{|c|}{$\mathbf{N}$ level } & \multirow[b]{2}{*}{$\hat{\mathbf{Y}}=\mathbf{a}+\mathbf{b x}-\mathbf{c} \mathbf{x}^{2}$} & \multirow{2}{*}{$\underset{\text { ton }}{\hat{\hat{Y}}_{\max }}$} & \multirow{2}{*}{$\underset{\operatorname{kg}}{\underline{X}_{\max }}$} \\
\hline & $\begin{array}{l}40 \mathrm{~kg} \\
\mathrm{~N} / \mathrm{fad} \\
\end{array}$ & $\begin{array}{l}80 \mathrm{~kg} \\
\mathrm{~N} / \mathrm{fad} \\
\end{array}$ & $\begin{array}{c}120 \mathrm{~kg} \mathrm{~N} / \\
\mathrm{fad}\end{array}$ & & & \\
\hline \multirow{2}{*}{ Berseem } & $\mathrm{A}$ & $\mathrm{A}$ & $\mathrm{A}$ & \multirow{2}{*}{$2.70+1.61 x-0.59 x^{2}$} & \multirow{2}{*}{3.80} & \multirow{2}{*}{54.58} \\
\hline & $2.70 \mathrm{a}$ & $3.72 \mathrm{a}$ & $3.56 \mathrm{~b}$ & & & \\
\hline \multirow{2}{*}{ Wheat } & $\mathrm{B}$ & $\mathrm{AB}$ & $\mathrm{A}$ & \multirow{2}{*}{$3.15+0.38 x$} & \multirow{2}{*}{ Linear } & \multirow{2}{*}{ Linear } \\
\hline & $3.15 \mathrm{a}$ & $3.57 \mathrm{a}$ & $4.08 \mathrm{a}$ & & & \\
\hline
\end{tabular}

$\hat{\mathrm{Y}}_{\max }$ : predicted maximum average

$\mathrm{X}_{\max }$ : predicted maximum $\mathrm{N}$ level

TABLE 5-c. Total yield (ton/ fad) of maize as affected by preceding crop treatments and $\mathrm{N}$ level interaction (combined data).

\begin{tabular}{|c|c|c|c|c|c|c|}
\hline \multirow{2}{*}{$\begin{array}{l}\text { Preceding crop } \\
\text { treatments }\end{array}$} & \multicolumn{3}{|c|}{ N level } & \multirow[b]{2}{*}{$\hat{\mathbf{Y}}=\mathbf{a}+\mathbf{b x}-\mathbf{c} \mathbf{x}^{2}$} & \multirow{2}{*}{$\begin{array}{l}\hat{\hat{Y}}_{\max } \\
\text { ton// } \\
\text { fad }\end{array}$} & \multirow{2}{*}{ 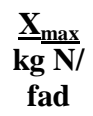 } \\
\hline & $\begin{array}{r}40 \mathrm{~kg} \\
\mathrm{~N} / \mathrm{fad} \\
\end{array}$ & $\begin{array}{r}80 \mathrm{~kg} \\
\mathrm{~N} / \mathrm{fad} \\
\end{array}$ & $\begin{array}{l}120 \mathrm{~kg} \\
\mathrm{~N} / \mathrm{fad}\end{array}$ & & & \\
\hline \multirow{2}{*}{ Berseem } & $\mathrm{B}$ & $\mathrm{A}$ & $\mathrm{A}$ & \multirow{2}{*}{$5.84+2.38 x-0.86 x^{2}$} & \multirow{2}{*}{7.49} & \multirow{2}{*}{55.56} \\
\hline & $5.84 \mathrm{a}$ & $7.36 \mathrm{a}$ & $7.17 \mathrm{~b}$ & & & \\
\hline \multirow{2}{*}{ Wheat } & $\mathrm{C}$ & $\mathrm{B}$ & $\mathrm{A}$ & \multirow{2}{*}{$5.92+1.12 x$} & \multirow{2}{*}{ Linear } & \multirow{2}{*}{ Linear } \\
\hline & $5.92 \mathrm{a}$ & $6.94 \mathrm{a}$ & $7.77 \mathrm{a}$ & & & \\
\hline
\end{tabular}

$\hat{\mathrm{Y}}_{\max }$ : predicted maximum average

$\mathrm{X}_{\text {max }}$ : predicted maximum $\mathrm{N}$ level

\section{References}

Abd Alla, A.A. (2005) Maize yield potentiality in response to bio and mineral nitrogen fertilizers under drip irrigation regimes in the newly reclaimed soils. J. Agric. Sci. Mansoura Univ. 30 (10), 5765-5779.

Abd El-Rheem, Kh. M., Zaghloul, Sahar M. and Mahdy, Hayam A. A. (2015) Effect of phosphorus and potassium fertilization on growth and yield of corn plants under different natural soil amendments. Sci. Agric. 9 (2), 70-75.

Abdul Galil, A.A., Basha, H.A., Mowafy, S.A.E. and Mohamed, Seham M. (2003) Effect of phosphorus addition on the response of four wheat cultivars to $\mathrm{N}$ fertilization level under sandy soil conditions. Minufiya J. Agric. Res. 28 (1), 1-22.

Atia, A.A. and Mahmoud, A.A. (2006) Economic study to evaluate the nitrogen response curve in maize. J. Agric. Sci. Mansoura Univ. 31(4), 1837-1846.

Egypt. J. Agron.38, No. 2 (2016) 
Bagayako, M., Buekert, A., Lung, G., Bationo, A. and Romheld, V. (2000) Cereal/legume rotation effects on cereal growth in Sudano-Sahelian West Africa: Soil mineral nitrogen, mycorrhizae and nematodes. Plant Soil, 218, 103-116.

Chan, K.Y. and Heenan, D.P. (1996) The influence of crop rotation on soil structure and soil physical properties under conventional tillage. Soil Tillag, 37, 113-125.

Darwich, M.M.B. (2013) Effect of $\mathrm{N}$ rates, compost and humic acid treatments on growth and yield components of maize. Ph. D. Thesis in Agron., Fac. Agric. Mansoura Univ. Egypt.

Duncan, D.B. (1955) Multiple Range and Multiple "F" Test. Biometrics, 11,1-42.

El-Azab, A.A.S. (2012) Response of maize to organic and mineral fertilization under foliar application treatments. Ph. D. Thesis in Agron., Fac. Agric. Mansoura Univ. Egypt.

El-Murshedy, W.A. (2002) Response of some maize cultivars to nitrogen fertilization under two farming system. J. Agric. Sci. Mansoura Univ. 27(5), 2821-2835.

FAOSTAT. (2014) Food and Agricultural Organization of the United Nations (FAO), FAO Statistical Database, 2013, from http://faostat.fao.org. December 2015.

Ghazy, M.A. (2004) Effect of water regime, nitrogen level and zinc application on maize yield and its water relations. J. Agric. Sci. Mansoura Univ. 29 (3), 1563-1572.

Gomez, K.N. and Gomez, A.A. (1984) "Statistical Procedures for Agricultural Res.", John Wiley and Sons, New York, $2^{\text {nd }}$ ed. p.68.

Hegazy, M.H., Genaidy, S.A. Abd El-Magid, A.A. and Khalil, K.M. (1996) Nitrogen and phosphorus fertilization for corn (Zea mays L.) in relation to some untraditional fertilizer at Kafer El-Shikh soil. J. Agric. Sci. Mansours Univ. 21, 3367-3372.

Hussein, A.H.A. (2009) Phosphorus use efficiency by two varieties of corn at different phosphorus fertilizer application rates. Res. J. Applied Sci. 4, 85-93.

Kandil, E.E.E. (2013) Response of some maize hybrids (Zea mays L.) to different levels of nitrogenous fertilization. Journal of Applied Sciences Research, 9 (3), 1902-1908.

Karlen, A.H., Varvel, G.E., Bullock, D.G., and Cruse, R.H. (1994) Crop rotations for the $21^{\text {st }}$ century. Adv. Agron. 53, 1-45.

Mahama, G.Y. Vara Prasad, P.V., Roozeboom, K.L., Nippert, J.B. and Rice, C.W. (2016) Response of maize to cover crops, fertilizer nitrogen rates, and economic return. Agron. J. 108,17-31.

Masood, T., Gul, R., Munsif, F., Jalal, F., Hussain, Z. and Noreen, N. (2011) Effect of different phosphorus levels on the yield and yield components of maize. Sarhad J. Agric. 27, 167-180. 
Mazengia, W. (2011) Effects of methods and rates of phosphorus fertilizer application and planting methods on yield and related traits of maize (Zea mays L.) on soil of Hawassa area. Innovation Syst. Des. Eng. 2, 315-335.

MSTAT-C (1991) A microcomputer program for the design, management and analysis of agronomic research experiment. MSTAT Development Team, Michigan State University.

Neter, J., Wasserman, W. and Kutner, M.H. (1990) "Applied Liner Statistical Model". $3^{\text {rd }}$ ed. IRWIN, Boston, MA. USA.

Ogunlela, V.B., Amoruwa, G.M. Olongunde, O.O. (2005) Growth, yield components and micronutrient nutrition of field maize grown as affected by nitrogen fertilization and plant density. Nutr. Cycl. Agro-ecosyst. 17, 385-1314.

Omar, A.E.A. (2014) Effect of FYM and phosphorus fertilization on yield and its components of maize. Asian J. Crop Science, 6 (1), 15-26.

Saleem, A., Javed, H.I., Ali, Z. and Ullah, I. (2003) Response of maize cultivars to different NP-levels under irrigated condition in Peshawar Valley. Pakistan J. Biological Sci. 6 (14), 1229-1231.

Salem, M.A. (2000) Response of maize (Zea mays L.) growth and yield to chemical and biofertilization. Zagazig J. Agric. Res. 24, 845-858.

Shams, S.A.A. (2000) Effect of some preceding winter crops, nitrogen levels and zinc foliar application on grain yield of maize (Zea mays L.). Annals of Agric. Sci., Moshtohor, 38 (1), 47-63.

Skarlou, B. and Nuhas, A. (1981) Effect of phosphorus fertilizer labeled with $\mathrm{P}_{32}$ on maize growth in calcareous soils. Maize Abstract, 2 (1).

Snedecor, G.W. and Cochran, W.G. (1967) "Statistical Methods". $5^{\text {th }}$ ed. Iowa State Univ. Press, Iowa, USA.

Soliman, I.E. and Gharib, H.S. (2011) Response of weeds and maize (Zea mays L.) to some weed control treatments under different nitrogen fertilizer rates. Zagazig J. Agric. Res. 38 (2), 249-271.

Veenstra, J.J., Horwath, W.R. and Mitchell, J.P. (2007) Tillage and cover cropping effects on aggregate-protected carbon in cotton and tomato. Soil Sci. Soc. Am. J. 71, 362-371. doi:10.2136/sssaj2006.0229.

Wortmann, C.S., Dobermann, A.R., Ferguson, R. B., Hergert, G. W., Shapiro, C. A., Tarkalson, D.D. and Walters, D.T. (2009) High-yielding corn response to applied phosphorus, potassium, and sulfur in nebraska. Agronomy J. 101, 546-555.

Yusuf, A.A., Abaidoo, R.C., Iwuafor, E.N.O., Olufajo, O.O. and Sanginga, N. (2009) Rotation effects of grain legumes and fallow on maize yield, microbial biomass and chemical properties of an Alfisol in the Nigerian savanna. Agriculture. Ecosystem \& Environment, 129, 325-331.

Egypt. J. Agron.38, No. 2 (2016) 
Zivorad, V., Jovanovic, Z., Dumanovic, Z., Simic, M., Srdic, J., Dragigevic, V. and Spasojevic, I. (2013) Effect of long term crop rotation and fertilizer application on maize productivity. Turkish Journal of Field Crops,18 (2), 233-237.

(Received 24/4/2016; accepted 14/ 7/ 2016)

إستجابة الذرة الثامية الصفراء لتأثير المحصول السابق ومستوي التسميل النيتروجيني والفوسفاتي التيفي قسم المحاصيد السيل ـ كلية الزبكي اعة ـ جامعة الزقازيق ـالثرقيةـ مصر.

أجريت هذه الدراسة في مركز بحوث التجارب التابع لكلية الزراعة جامعة

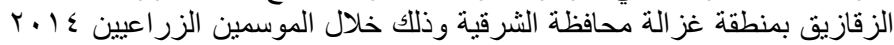

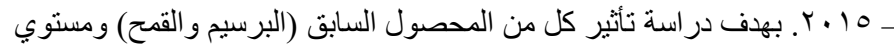

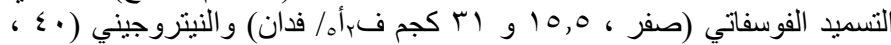

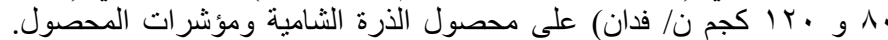
ويمكن تلخيص النتائج المتحصل عان عليها على النحو التالى:

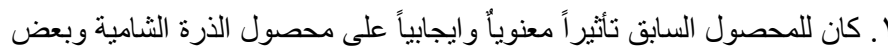

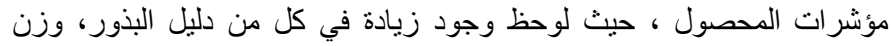

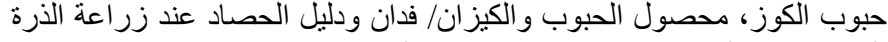

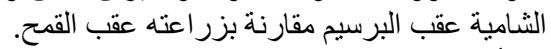

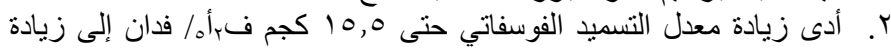

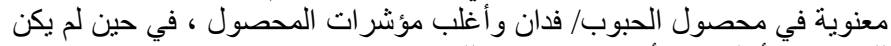

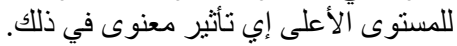

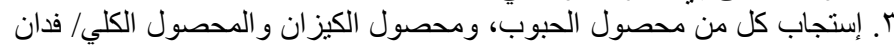

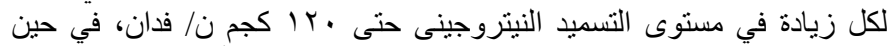

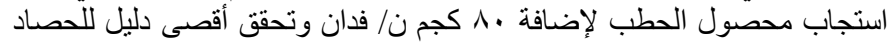

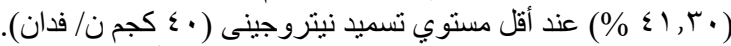

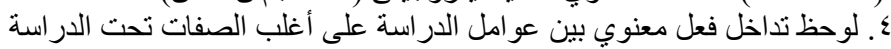

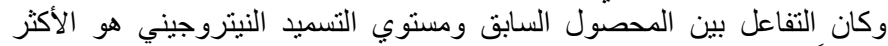

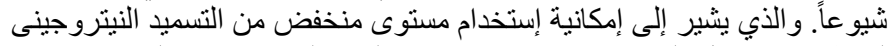

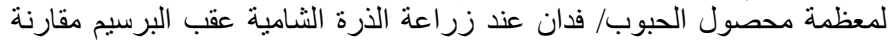

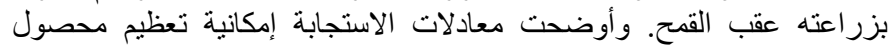

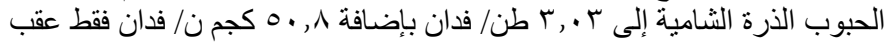

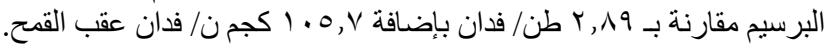

